\title{
Enhancing Butyrate Production, Ruminal Fermentation and Microbial Population through Supplementation with Clostridium saccharobutylicum
}

\author{
Michelle A. Miguel $^{1 \dagger}$, Sung Sill Lee ${ }^{2 \dagger}$, Lovelia L. Mamuad ${ }^{1}$, Yeon Jae Choi ${ }^{1}$, Chang Dae Jeong ${ }^{1}$, Arang Son ${ }^{1}$, \\ Kwang Keun $\mathrm{Cho}^{3}$, Eun Tae Kim ${ }^{4}$, Sang Bum Kim ${ }^{4}$, and Sang Suk Lee ${ }^{1 *}$ \\ ${ }^{1}$ Department of Animal Science and Technology, College of Bio-industry Science, Sunchon National University, Suncheon 57922, Republic of Korea \\ ${ }^{2}$ Division of Applied Life Science (BK21 Program) and Institute of Agriculture and Life Sciences (IALS), Gyeongsang National University, \\ Jinju 52828, Republic of Korea \\ ${ }^{3}$ Department of Animal Resources Technology, Gyeongnam National University of Science and Technology, Jinju 52828, Republic of Korea \\ ${ }^{4}$ Dairy Science Division, National Institute of Animal Science, Rural Development Administration, Cheonan 31000, Republic of Korea
}

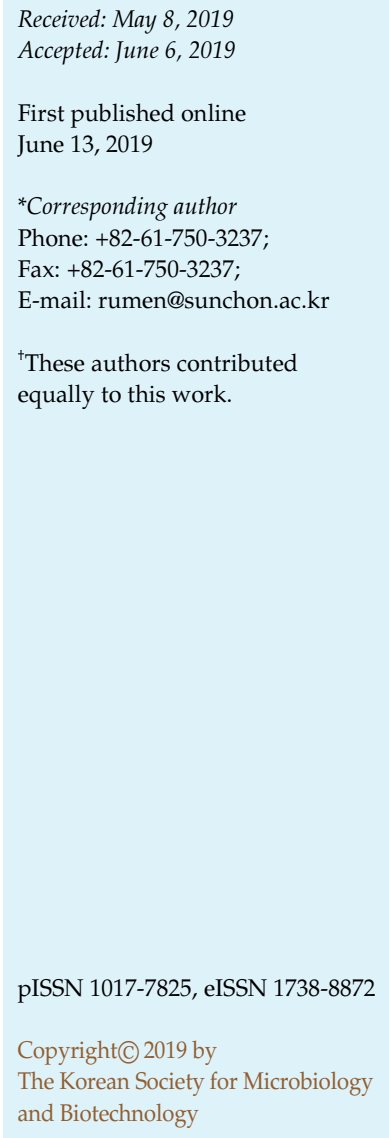

Butyrate is known to play a significant role in energy metabolism and regulating genomic activities that influence rumen nutrition utilization and function. Thus, this study investigated the effects of an isolated butyrate-producing bacteria, Clostridium saccharobutylicum, in rumen butyrate production, fermentation parameters and microbial population in Holstein-Friesian cow. An isolated butyrate-producing bacterium from the ruminal fluid of a Holstein-Friesian cow was identified and characterized as Clostridium saccharobutylicum RNAL841125 using 16S rRNA gene sequencing and phylogenetic analyses. The bacterium was evaluated on its effects as supplement on in vitro rumen fermentation and microbial population. Supplementation with $10^{6} \mathrm{CFU} / \mathrm{ml}$ Clostridium saccharobutylicum increased $(p<0.05)$ microbial crude protein, butyrate and total volatile fatty acids concentration but had no significant effect on $\mathrm{NH}_{3}-\mathrm{N}$ at $24 \mathrm{~h}$ incubation. Butyrate and total VFA concentrations were higher $(p<0.05)$ in supplementation with $10^{6} \mathrm{CFU} / \mathrm{ml}$ Clostridium saccharobutylicum compared with control, with no differences observed for total gas production, $\mathrm{NH}_{3}-\mathrm{N}$ and propionate concentration. However, as the inclusion rate $(\mathrm{CFU} / \mathrm{ml})$ of $\mathrm{C}$. saccharobutylicum was increased, reduction of rumen fermentation values was observed. Furthermore, butyrate-producing bacteria and Fibrobacter succinogenes population in the rumen increased in response with supplementation of C. saccharobutylicum, while no differences in the population in total bacteria, protozoa and fungi were observed among treatments. Overall, our study suggests that supplementation with $10^{6} \mathrm{CFU} / \mathrm{ml} \mathrm{C}$. saccharobutylicum has the potential to improve ruminal fermentation through increased concentrations of butyrate and total volatile fatty acid, and enhanced population of butyrate-producing bacteria and cellulolytic bacteria F. succinogenes.

Keywords: Butyric acid, Clostridium saccharobutylicum, Holstein cow, rumen fermentation, microbial population

\section{Introduction}

The rumen consists of a dense and diverse microbial ecosystem [1] and has the ability to convert fibrous plant material and non-protein nitrogen into important products, such as short-chain fatty acids and microbial protein [2] . In ruminants, rumen fermentation plays an important role in feed digestion and microbial production. In the last decades, attempts have been made to improve rumen productivity through manipulation of the rumen environment. Modulation of the rumen environment can enhance digestibility and nutrient utilization in the animals. One approach that is widely used is the application of natural products such as microbial additives. Microbial additives are found to be 
beneficial as they promote digestion and intestinal hygiene [3], enhance animal performance and reduce the usage of antibiotics [4-6]. Microbial additives have been shown to improve ruminant animal performance in terms of live weight gain and milk production by $7-8 \%$ [7]. Thus, microbial additives have been used for many years to supplement the diets of farm animals and humans [8], and as an inoculant to improve feed quality.

Butyric acid is a short-chain fatty acid produced by anaerobic fermentation of dietary substrates in the rumen and large intestine [9]. Butyrate serves as a major energy source for epithelial cells in ruminants [10] and is significant in maintaining colonic health in both humans and animals [11]. Most importantly, butyrate stimulates epithelial cell proliferation leading to improved feed utilization by the animal. Moreover, butyrate also possesses other important functions in the intestinal epithelium, such as prevention of certain types of colitis [12]. Sodium butyrate supplementation has been reported to improve growth performance in calves [13]. Furthermore, several studies have shown that butyrate affects several other parameters, such as the mucosal barrier, feed passage, microbiota, immune system, and pathogens [14], and provides beneficial effects in improving health and performance of the host [15].

Due to the increasing demand of consumers for naturally made products, the production of butyric acid by microbial fermentation has attracted much attention. Several anaerobic bacteria can produce butyric acid as a major fermentation product by utilizing various substrates. Butyrate-producing bacteria can be found in environmentand host-associated sites, including the rumen, mouth and large intestine [16]. Butyrate-producing bacteria are associated with gastrointestinal health in humans and various animal species [17] and play an important role in the degradation of proteins, nucleic acids and structural and storage plant polysaccharides [18]. Due to its multiple beneficial effects on the host, butyrogenic bacteria are considered to have a potential use as probiotics. Thus, we aimed to enhance butyrate production by supplementing Clostridium saccharobutylicum in the rumen in vitro and to evaluate its effect on rumen fermentation parameters and microbial population in Holstein-Friesian cow.

\section{Materials and Methods}

Isolation, Characterization, and Molecular Identification of Butyrate-Producing Bacteria

Butyrate-producing bacteria were isolated from the rumen contents of a 48-month-old, rumen-cannulated Holstein-Friesian cow $(600 \pm 47 \mathrm{~kg})$. The animal was fed twice daily with concentrate feed (NongHyup Co., Korea) and rice straw at a 2:8 ratio. Ruminal fluid was collected before feeding and obtained by straining the rumen contents through four layers of surgical gauze and pooled in an amber bottle with an oxygen-free headspace immediately after collection. The collected rumen fluid was sealed, maintained at $39^{\circ} \mathrm{C}$, and immediately transported to the laboratory for bacterial isolation. The management of animals was approved by the Sunchon National University Committee on Animal Care (2016).

\section{Media Preparation and Isolation of Bacteria from Rumen}

One milliliter of rumen sample was placed in sterile tubes and homogenized in $9 \mathrm{ml}$ of anaerobic medium containing soluble starch, glucose and cellobiose as energy sources (M2GSC) [19] $\mathrm{pH} 6$ containing: $10.0 \mathrm{~g} / \mathrm{l}$ of casitone, $2.5 \mathrm{~g} / 1$ of yeast extract, $4.0 \mathrm{~g} / \mathrm{l}$ $\mathrm{NaHCO}_{3}, 2.0 \mathrm{~g} / 1$ glucose, $2.0 \mathrm{~g} / 1$ soluble starch, $2.0 \mathrm{~g} / \mathrm{l}$ cellobiose, $300 \mathrm{ml}$ of clarified rumen fluid, $1.0 \mathrm{~g} / \mathrm{l}$ of cysteine $\mathrm{HCl}, 150 \mathrm{ml}$ of Mineral Solution I ( $3.0 \mathrm{~g} / 1$ of $\left.\mathrm{K}_{2} \mathrm{HPO}_{4}\right), 150 \mathrm{ml}$ of Mineral Solution II $\left(3.0 \mathrm{~g} / \mathrm{l} \quad \mathrm{KH}_{2} \mathrm{PO}_{4}, \quad 6.0 \mathrm{~g} / \mathrm{l} \quad\left(\mathrm{NH}_{4}\right)_{2} \mathrm{SO}_{4}, \quad 6.0 \mathrm{~g} / \mathrm{l} \quad \mathrm{NaCl}, \quad 0.6 \mathrm{~g} / \mathrm{l}\right.$ $\left.\mathrm{MgSO}_{4} \cdot 7 \mathrm{H}_{2} \mathrm{O}, 0.6 \mathrm{~g} / 1 \mathrm{CaCl}_{2}\right)$, and $1.0 \mathrm{~g}$ of resazurin $(1 \% \mathrm{w} / \mathrm{v})$. The medium was aseptically added in the bottle and flushed with $\mathrm{CO}_{2}$ according to the anaerobic Hungate method [20]. This diluent corresponded to the first 10 -fold dilution, which was then mixed by vortexing to form homogenized suspension. From this suspension, it was subsequently diluted by 10 -fold serial dilutions through to a $10^{-9}$ dilution.

Anaerobic M2GSC medium containing $0.75 \%$ agar was prepared in $16 \times 125 \mathrm{~mm}$ Hungate tubes sealed with butyl septum stoppers and inoculated with $0.5 \mathrm{ml}$ aliquots of appropriate serial dilutions. Roll tubes were incubated at $37^{\circ} \mathrm{C}$ for 24 to $48 \mathrm{~h}$ prior to the picking of colonies from each sample. Picked colonies were subsequently inoculated in the same medium until purified. Purified cultures were grown in broths of M2GSC at $37^{\circ} \mathrm{C}$ for 24 to $48 \mathrm{~h}$ and used for the determination of fermentation products by high-performance liquid chromatography (HPLC) and DNA extraction for molecular identification of the isolates.

\section{Analysis of Butyric Acid Concentration}

The butyric acid produced by the bacterial isolates was compared with C. butyricum as positive control and analyzed using HPLC. Short-chain fatty acid concentrations were analyzed using an Agilent 1200 Series HPLC System (Agilent Technologies, USA) with a UV detector set at 210 and $220 \mathrm{~nm}$. Samples were eluted isocratically with $0.0085 \mathrm{~N} \mathrm{H}_{2} \mathrm{SO}_{4}$ at a flow rate of $0.6 \mathrm{ml} / \mathrm{min}$ and a column temperature of $35^{\circ} \mathrm{C}$.

\section{$16 S$ rRNA Sequence and Phylogenetic Analysis}

Isolates producing high butyric acid concentrations were identified by sequencing the $16 \mathrm{~S}$ ribosomal RNA (16S rRNA) gene using the 27F (5'-AGAGTTTGATCMTGGCTCAG-3') and 1492R (5'-TACGGYTACCTTGTTACGACTT-3') primers [21]. The gene sequences obtained from the isolates were compared with the $16 \mathrm{~S}$ 
rRNA sequences available in GenBank using the Basic Local Alignment Search Tool (BLAST) [22] and EzBioCloud database [23]. Multiple gene sequences were aligned using ClustalW [24] within the Molecular Evolutionary Genetics Analysis (MEGA) version 6 [25] to determine the approximate phylogenetic affiliations. The phylogenetic tree was constructed using the neighbor-joining method [26] with pair-wise comparison and with evolutionary distances computed using the Kimura 2-parameter method [27]. Reliability of the tree topology was assessed with the bootstrap method using 1000 replications [28]. Only bootstrap values greater than $50 \%$ are shown on the internal nodes.

\section{Cultivation of $C$. saccharobutylicum RNAL841125}

Clostridium saccharobutylicum RNAL841125 was deposited in the Korean Culture Center of Microorganisms (KCCM). The bacterial colonies of the $C$. saccharobutylicum RNAL841125 were maintained in clostridial growth medium composed of: $2.0 \mathrm{~g} / 1 \mathrm{~K}_{2} \mathrm{HPO}_{4}$ $0.75 \mathrm{~g} / 1 \mathrm{KH}_{2} \mathrm{PO}_{4}, 1.5 \mathrm{~g} / 1 \mathrm{MgSO}_{4} \cdot 7 \mathrm{H}_{2} \mathrm{O}, 0.017 \mathrm{~g} / 1 \mathrm{MnSO}_{4} \cdot 5 \mathrm{H}_{2} \mathrm{O}$, $0.01 \mathrm{~g} / 1 \mathrm{FeSO}_{4} \cdot 7 \mathrm{H}_{2} \mathrm{O}, 2.0 \mathrm{~g} / 1\left(\mathrm{NH}_{4}\right)_{2} \mathrm{SO}_{4}, 5.0 \mathrm{~g} / 1 \mathrm{NaCl}, 2.0 \mathrm{~g} / 1$ asparagine, $0.004 \mathrm{~g} / 1 \mathrm{p}$-aminobenzoic acid, $15.0 \mathrm{~g} / 1$ yeast extract, and $50.0 \mathrm{~g} / \mathrm{l}$ glucose. The $\mathrm{pH}$ of the medium was adjusted to 6.8 . The headspace of the bottle was purged with $\mathrm{N}_{2}$ gas. The medium was dispensed anaerobically under an $\mathrm{O}_{2}$-free $\mathrm{N}_{2}$ atmosphere and autoclaved at $121^{\circ} \mathrm{C}$ for $15 \mathrm{~min}$. Bacterial cultures were grown anaerobically and incubated at $37^{\circ} \mathrm{C}$ for $24-48 \mathrm{~h}$. Bacterial growth was monitored by optical density (OD) using a spectrophotometer at $600 \mathrm{~nm}$.

\section{Substrate Utilization and Enzyme Activities}

Substrate utilization of RNAL841125 isolate was tested using an API $50 \mathrm{CH}$ test kit (Biomérieux, France). Analyses for enzyme activities were carried out for CMCase, FPase xylanase, pectin methyl esterase, polygalactouranase and $\alpha$-amylase using carboxymethyl cellulose (CMC), filter paper, pectin, xylan and starch as substrate, respectively. The enzyme activities were determined by estimating the amount of reducing sugar liberated from the enzymatic reaction from respective substrate dissolved in appropriate buffer by dinitrosalycilic acid (DNS) [29]. One unit of enzyme was defined as the amount of enzyme that released $1 \mu \mathrm{mol}$ of glucose per min.

\section{Rumen Fluid Collection and In Vitro Fermentation}

All animal care procedures were conducted in accordance with the guidelines approved by the Sunchon National University Committee on Animal Care (SCNU IACUC-2018-01). Three rumen-cannulated Holstein cows weighing $600 \pm 47 \mathrm{~kg}$ were fed twice daily with total mixed ration (Table 1 ) and Italian ryegrass (7:3 ratio). Ruminal fluid was collected before feeding and obtained by straining the rumen contents through four layers of surgical gauze and pooled in an amber bottle with an oxygen-free headspace immediately after collection. The collected rumen fluid was sealed, maintained at $39^{\circ} \mathrm{C}$, and immediately transported in the laboratory.
Table 1. Feed composition used in the study.

\begin{tabular}{lc}
\hline \multicolumn{1}{c}{ Composition } & Percentage \\
\hline Soybean meal & 9.27 \\
Lupin seed & 11.07 \\
Dried distillers' grains & 5.92 \\
Rice bran & 5.15 \\
Corn & 36.94 \\
Mushroom media & 18.40 \\
Protein & 11.07 \\
Salt & 0.39 \\
Limestone & 0.77 \\
Vitamin & 1.03 \\
\hline
\end{tabular}

The buffer medium was prepared following the method described by Asanuma et al. [30]. The buffer was autoclaved at $121^{\circ} \mathrm{C}$ for $15 \mathrm{~min}$, maintained in a $39^{\circ} \mathrm{C}$ water bath, and flushed with $\mathrm{CO}_{2}$ gas, and the $\mathrm{pH}$ was adjusted to 6.9 using $10 \mathrm{~N} \mathrm{NaOH}$. The experiment was conducted under a constant flow of $\mathrm{CO}_{2}$ gas on the rumen-buffered medium to ensure anaerobic conditions. The particle-free rumen fluid and buffer medium were mixed at a ratio of 1:3 $(\mathrm{v} / \mathrm{v})$. After mixing, $100 \mathrm{ml}$ of the mixed buffered rumen fluid was anaerobically transferred into the serum bottles containing $1.0 \mathrm{~g}$ dry matter substrate of total mixed ration and Italian ryegrass (70:30 ratio at DM basis) and treatments were anaerobically inoculated into the serum battles under a constant flow of $\mathrm{CO}_{2}$ gas. Treatments consisted of without inoculant (Control), supplementation with $10^{6} \mathrm{CFU} / \mathrm{ml}, 10^{7} \mathrm{CFU} / \mathrm{ml}$, or $10^{8} \mathrm{CFU} / \mathrm{ml}$ of C. saccharobutylicum $\left(10^{6} \mathrm{Cs}, 10^{7} \mathrm{Cs}\right.$, and $10^{8} \mathrm{Cs}$, respectively), and supplementation with $50 \mathrm{mM}$ of butyric acid (BA) (Sigma, USA). The serum bottles were capped with a butyl rubber stopper, sealed with an aluminum cap, and incubated at $39^{\circ} \mathrm{C}$ in a shaking incubator set at $120 \mathrm{rpm}$. Three replicates were performed for all treatments and incubation times.

\section{Analysis of In Vitro Rumen Fermentation Parameters}

Rumen fermentation characteristics, including total gas production, $\mathrm{pH}$, ammonia-nitrogen $\left(\mathrm{NH}_{3}-\mathrm{N}\right)$, microbial crude protein $(\mathrm{MCP})$, and volatile fatty acid (VFA) concentrations were examined at the end of each incubation period. Two one-milliliter samples of rumen fluid from each serum bottle were collected in microcentrifuge tubes and maintained at $-80^{\circ} \mathrm{C}$ until further analysis of $\mathrm{NH}_{3}-\mathrm{N}$, VFA concentrations and microbial population.

Total gas production was measured from each serum bottle after incubation using a pressure sensor (Laurel Electronics, Inc., USA). The $\mathrm{pH}$ values of the rumen samples were measured immediately after opening each serum bottle using a digital $\mathrm{pH}$ meter (Mettler Toledo, Switzerland). For $\mathrm{NH}_{3}-\mathrm{N}$ and VFA analyses, the ruminal fluid samples were centrifuged at $14,000 \mathrm{rpm}$ for $15 \mathrm{~min}$ at $4^{\circ} \mathrm{C}$ and the supernatant was then used for the analysis. Rumen $\mathrm{NH}_{3}-\mathrm{N}$ levels were determined according to a colorimetric 
method developed by Chaney and Marbach [31] using a Libra S22 spectrophotometer (Biochrom Ltd., England) set at $630 \mathrm{~nm}$. MCP was estimated following the method used by Castillo-Lopez et al. [32]. VFA concentrations were analyzed using an Agilent 1200 Series HPLC System (Agilent Technologies) with a UV detector set at 210 and $220 \mathrm{~nm}$. Samples were eluted isocratically with $0.0085 \mathrm{~N} \mathrm{H}_{2} \mathrm{SO}_{4}$ at a flow rate of $0.6 \mathrm{ml} / \mathrm{min}$ and a column temperature of $35^{\circ} \mathrm{C}$.

\section{DNA Extraction}

Microcentrifuge tubes containing ruminal fluid samples were centrifuged at $14,000 \mathrm{rpm}$ for $15 \mathrm{~min}$ at $4^{\circ} \mathrm{C}$. The supernatant was then discarded and the isolated pellets were used for the extraction of total microbial genomic DNA using a FastDNA SPIN Kit for Soil (MP Biomedicals, LLC, USA) following the manufacturer's protocol. The DNA concentration and quality were measured using an Optizen NanoQ spectrophotometer (Optizen, Korea). The DNA samples were stored at $-20^{\circ} \mathrm{C}$ until analysis.

\section{Quantitative Real-Time PCR Analyses}

The population sizes of total bacteria, protozoa, general fungi and select bacterial species were quantified using SYBR Greenbased quantitative real-time PCR (qPCR) using the Eco Real-Time PCR (Illumina, USA). The primers used for each microbial group are shown in Table 2. In addition, the butyrate kinase (buk) gene, which is involved in the production of butyrate, was also quantified. The reaction mixture was prepared in a total volume of $20 \mu \mathrm{l}$ containing $10 \mu \mathrm{l}$ of $2 x$ QuantiSpeed SYBR No-Rox mix (PhileKorea, Korea), $0.8 \mu \mathrm{l}$ of each $10 \mu \mathrm{M}$ primer, and $8.4 \mu \mathrm{l}$ template DNA at a concentration of $50 \mathrm{ng} / \mu \mathrm{l}$ in sterile distilled water. The qPCR reactions were performed under thermal cycle conditions of one cycle at $50^{\circ} \mathrm{C}$ for $2 \mathrm{~min}$, and $95^{\circ} \mathrm{C}$ for $2 \mathrm{~min}$, followed by 40 cycles at $95^{\circ} \mathrm{C}$ for $15 \mathrm{sec}, 60^{\circ} \mathrm{C}$ for $1 \mathrm{~min}$ and $72^{\circ} \mathrm{C}$ for $30 \mathrm{sec}$. For all PCR runs, standards, negative controls (no DNA), and samples were run in triplicate.

\section{Statistical Analysis}

Data were subjected to analysis of variance (ANOVA) using the general linear model (GLM) for a completely randomized design. All treatments were conducted in triplicate and Duncan's multiple range test was used to identify differences between specific treatments. For the in vitro rumen fermentation, the linear effects of C. saccharobutylicum supplementation were analyzed using orthogonal polynomial coefficients to describe the functional relationships among the control and treatment groups. Differences with $p$ values less than 0.05 were considered statistically significant. Data analysis was carried out using Statistical Analysis Systems (SAS) version 9.3 (SAS Institute Inc., USA).

Table 2. Primers used for real-time PCR assay.

\begin{tabular}{|c|c|c|}
\hline Target & Name & Sequence $\left(5^{\prime}\right.$ to $\left.3^{\prime}\right)$ \\
\hline \multicolumn{3}{|l|}{ A. Microbial quantification } \\
\hline \multirow[t]{2}{*}{ 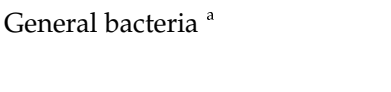 } & $1114-\mathrm{F}$ & CGGCAACGAGCGCAACCC \\
\hline & $1275-\mathrm{R}$ & CCATTGTAGCACGTGTGTAGCC \\
\hline \multirow[t]{2}{*}{ Protozoa ${ }^{\mathrm{b}}$} & $316-\mathrm{F}$ & GCTTTCGWTGGTAGTGTATT \\
\hline & $539-\mathrm{R}$ & CTTGCCCTCYAATCGTWCT \\
\hline \multirow[t]{2}{*}{ General anaerobic fungi ${ }^{a}$} & GAF-F & GAGGAAGTAAAAGTCGTAACAAGGTTTC \\
\hline & GAF-R & CAAATTCACAAAGGGTAGGATGATT \\
\hline \multirow[t]{2}{*}{ F. succinogenes ${ }^{a}$} & $586-\mathrm{F}$ & GTTCGGAATTACTGGGCGTAAA \\
\hline & $706-\mathrm{R}$ & CGCTGCCCCCTGAACTATC \\
\hline \multicolumn{3}{|l|}{ B. Microbial crude protein (MCP) } \\
\hline \multirow[t]{3}{*}{ Bacterial crude protein $(\mathrm{BCP})^{\mathrm{c}}$} & BAC338-F & ACTCCTACGGGAGGCAGCAG \\
\hline & Probe & FAM/TGCCAGCAGCCGCGGTAATAC/TAMRA \\
\hline & BAC805-R & GACTACCAGGGTATCTAATCC \\
\hline \multirow[t]{3}{*}{ Protozoal crude protein $(\mathrm{PCP})^{\mathrm{d}}$} & $\mathrm{F}$ & GCTTTCGATGGTAGTGTATT \\
\hline & Probe & FAM/CGGAAGGCAGCAGGCGC/TAMRA \\
\hline & $\mathrm{R}$ & ACTTGCCCTCTAATCGTACT \\
\hline \multicolumn{3}{|l|}{ C. Butyrate-producing bacteria } \\
\hline \multirow[t]{2}{*}{ butyrate kinase $(b u k)$ gene $^{\mathrm{e}}$} & G_buk_F & TGCTGTWGTTGGWAGAGGYGGA \\
\hline & G_buk_R & GCAACIGCYTTTTGATTTAATGCATGG \\
\hline
\end{tabular}

${ }^{\mathrm{a}}$ Denman and McSweeney [70]; ${ }^{\mathrm{b}}$ Sylvester et al. [71]; ${ }^{\mathrm{c}} Y u$ et al. [72]; ${ }^{\mathrm{d}}$ Sylvester et al. [73]; ${ }^{\mathrm{e}}$ Vital et al. [16]. 


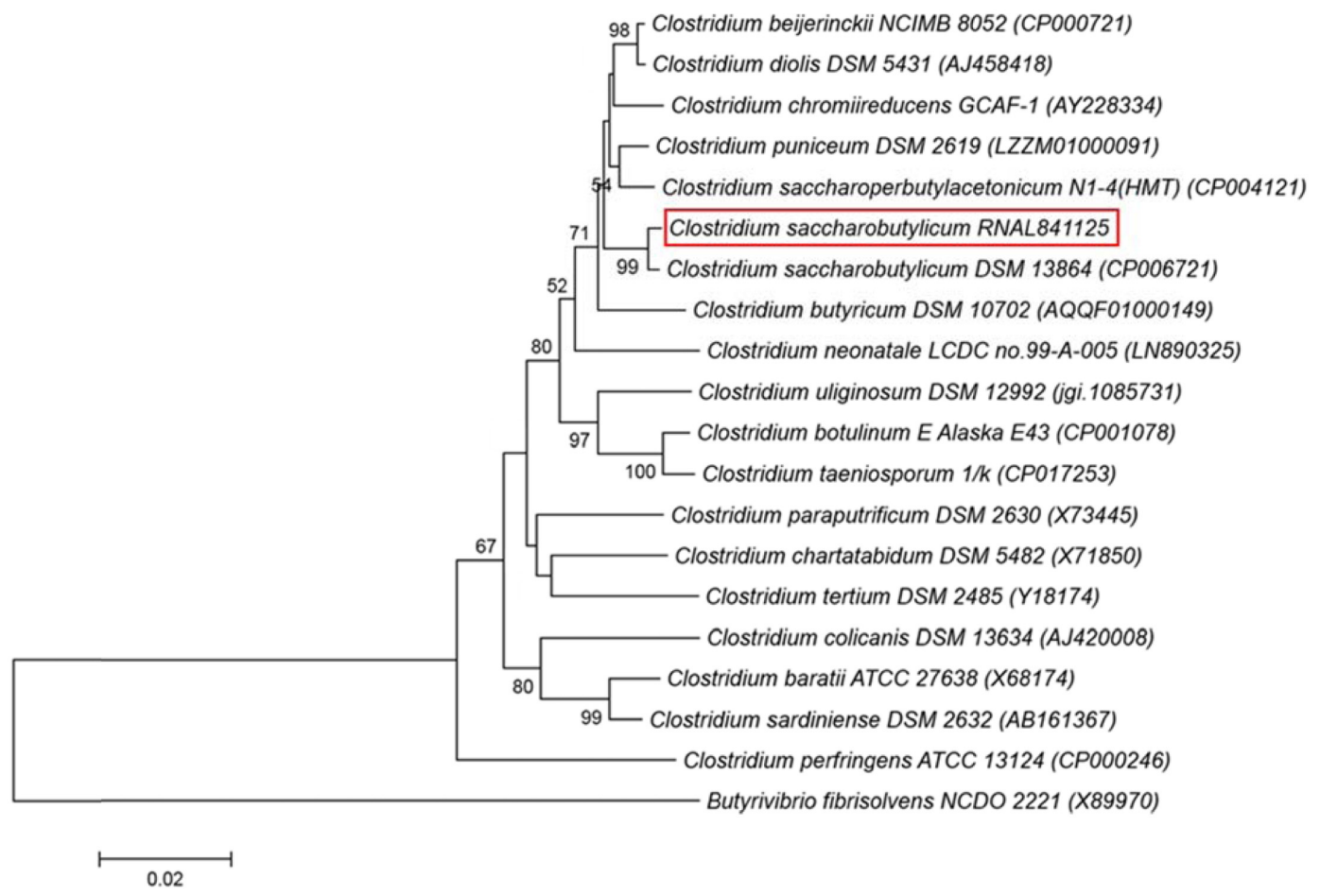

Fig. 1. Phylogenetic tree based on comparison of $16 \mathrm{~S}$ rRNA gene sequences, indicating the taxonomic position of Clostridium saccharobutylicum RNAL841125.

The phylogenetic tree was constructed using the neighbour-joining method. Bootstrap values, expressed as 1000 replicates, are given at branching points. Only bootstrap values $>50 \%$ are shown on the internal nodes. Butyrivibrio fibrisolvens was used as an outgroup and the bar represents 0.02 substitutions per nucleotide.

\section{Results}

\section{Identification and Characterization of Butyrate-Producing Bacteria}

A potential butyrate-producing bacteria was isolated from the rumen. The $16 \mathrm{~S}$ rRNA gene sequencing and phylogenetic analyses demonstrated that this isolate was $99 \%$ similar to C. saccharobutylicum DSM $13864^{\mathrm{T}}$ [33]. The isolate was deposited in the Korean Culture Center of Microorganisms (KCCM) as C. saccharobutylicum RNAL841125 (Fig. 1) with NCBI GenBank accession number MH032748. Only bootstrap values $>50 \%$ were shown on the internal nodes, and Butyrivibrio fibrisolvens was used as an outgroup and the bar represents 0.02 substitutions per nucleotide position.

The butyrate production level of C. saccharobutylicum RNAL841125 was compared with the standard butyrateproducing bacteria, C. butyricum. Significantly higher levels $(p<0.05)$ of propionate and butyrate were produced by C. saccharobutylicum RNAL841125 (20.46 and $42.39 \mathrm{mmol} / \mathrm{l}$, respectively) than C. butyricum (18.79 and $19.11 \mathrm{mmol} / \mathrm{l}$, respectively) (data not shown). The substrate utilization test using the API $50 \mathrm{CH}$ identification system revealed that RNAL841125 isolate could utilize 28 types of sugars as substrates. The $C$. saccharobutylicum profile revealed that the isolate metabolized D-arabinose, L-arabinose, ribose, D-xylose, L-xylose, glucose, fructose, mannose, inozitol, $\alpha$-methyl-D-mannoside, $\alpha$-methyl-D-glucoside, amygdalin, salicin, maltose, lactose, melibiose, sucrose, trehalose, raffinose, starch, glycogen, xylitol, gentiobiose, D-turanose, D-fucose, L-fucose, D-arabitol and gluconate. Additionally, analysis of the growth of C. saccharobutylicum RNAL841125 on CMC, filter paper (Whatman filter paper No. 1), xylan, pectin, and starch as substrates revealed that the isolate had weak fermentation on CMC and filter paper and, no fermentation was seen in pectin (data not shown). The enzyme activities of the bacteria using $\mathrm{CMC}$, filter paper (Whatman filter paper No. 1), xylan, pectin and starch are shown in Fig. 2. The results indicated that the use of CMC and filter paper as substrates produced low amounts of enzyme in comparison with xylan and starch. 


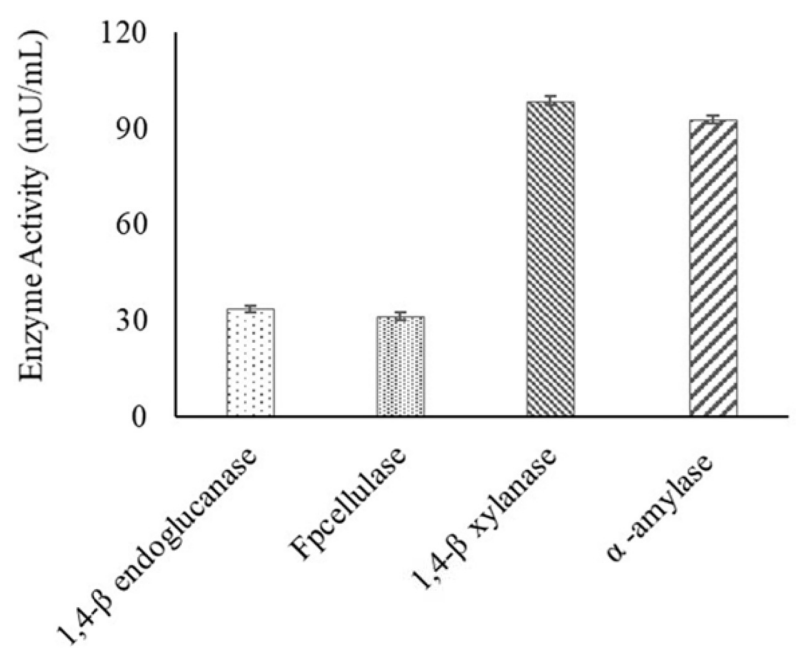

Enzymes

Fig. 2. Enzyme activity of C. saccharobutylicum RNAL841125.

Effects of C. saccharobutylicum Supplementation on In Vitro Rumen Fermentation Parameters

The effects of supplementation with C. saccharobutylicum on rumen fermentation parameters are shown in Table 3. In response to supplementation with $10^{6} \mathrm{CFU} / \mathrm{ml} \mathrm{C}$. saccharobutylicum, total gas production at 6 and $12 \mathrm{~h}$ were higher $(p<0.05)$ compared to the control and other treatments. Meanwhile, treatment with $10^{6} \mathrm{CFU} / \mathrm{ml} \mathrm{C}$. saccharobutylicum and control has similar gas production and significantly higher $(p<0.05)$ value than the other treatments at $24 \mathrm{~h}$. The rumen $\mathrm{pH}$ values after 6 and $24 \mathrm{~h}$ of incubation were lower $(p<0.05)$ in treatments supplemented with $C$. saccharobutylicum compared to the control and treatment with $50 \mathrm{mM}$ butyric acid. Ruminal $\mathrm{NH}_{3}-\mathrm{N}$ concentrations at $6 \mathrm{~h}$ were significantly higher $(p<0.05)$ in treatments supplemented with $C$. saccharobutylicum and $50 \mathrm{mM}$ butyric acid compared with the control. However, after $24 \mathrm{~h}$ incubation, no differences in the $\mathrm{NH}_{3}-\mathrm{N}$ concentration was observed among the treatments. On the other hand, results for microbial crude protein (MCP) are shown in Fig. 3. Microbial crude protein and bacterial crude protein were significantly higher $(p<0.05)$ following treatment with $10^{6} \mathrm{CFU} / \mathrm{ml}$ C. saccharobutylicum compared to other treatments. Meanwhile, no differences in the protozoal crude protein were observed among treatments. The effect of supplementation with $C$. saccharobutylicum on VFA concentrations are shown in Table 4. Higher concentrations $(p<0.05)$ of acetate were obtained in treatment with $10^{6} \mathrm{CFU} / \mathrm{ml}$ C. saccharobutylicum and $50 \mathrm{mM}$ butyric acid after $12 \mathrm{~h}$ incubation compared with other treatments. No differences were observed in the propionate concentrations between the treatment supplemented with $10^{6}$ and $10^{7} \mathrm{CFU} / \mathrm{ml} \mathrm{C}$. saccharobutylicum and control. Moreover, after 6 and $24 \mathrm{~h}$ of incubation, higher $(p<0.05)$ contents of butyrate and total volatile fatty acid were obtained following treatment with $10^{6} \mathrm{CFU} / \mathrm{ml}$ C. saccharobutylicum compared to control and other

Table 3. Effect of treatments on total gas production, $\mathrm{pH}$, and $\mathrm{NH}_{3}-\mathrm{N}$ during in vitro rumen fermentation at $0,6,12$, and $24 \mathrm{~h}$.

\begin{tabular}{|c|c|c|c|c|c|c|c|c|c|}
\hline \multirow{2}{*}{ Parameters } & \multirow{2}{*}{ Time (h) } & \multicolumn{5}{|c|}{ Treatments $^{1}$} & \multirow{2}{*}{$\mathrm{SEM}^{2}$} & \multicolumn{2}{|c|}{$p$ value } \\
\hline & & Control & $10^{6} \mathrm{Cs}$ & $10^{7} \mathrm{Cs}$ & $10^{8} \mathrm{Cs}$ & $\mathrm{BA}$ & & All & Linear $^{3}$ \\
\hline \multirow[t]{3}{*}{ Total gas (ml) } & 6 & $59.00^{b}$ & $62.33^{a}$ & $61.00^{\mathrm{ab}}$ & $60.67^{\mathrm{ab}}$ & $56.00^{c}$ & 0.741 & 0.0015 & 0.3350 \\
\hline & 12 & $72.67^{\mathrm{b}}$ & $76.67^{\mathrm{a}}$ & $75.33^{\mathrm{ab}}$ & $73.33^{\mathrm{b}}$ & $67.00^{c}$ & 0.941 & 0.0004 & 0.8674 \\
\hline & 24 & $84.67^{\mathrm{a}}$ & $85.00^{\mathrm{a}}$ & $83.00^{\mathrm{b}}$ & $81.67^{\mathrm{b}}$ & $78.00^{\mathrm{c}}$ & 0.480 & $<.0001$ & 0.0008 \\
\hline \multirow[t]{3}{*}{$\mathrm{pH}$} & 0 & 6.60 & 6.59 & 6.58 & 6.57 & 6.60 & 0.007 & 0.0560 & 0.0319 \\
\hline & 12 & 5.59 & 5.55 & 5.54 & 5.53 & 5.58 & 0.014 & 0.0974 & 0.0013 \\
\hline & 24 & $5.46^{\mathrm{a}}$ & $5.43^{\mathrm{b}}$ & $5.42^{\mathrm{b}}$ & $5.42^{\mathrm{b}}$ & $5.49^{\mathrm{a}}$ & 0.007 & 0.0001 & 0.0021 \\
\hline \multirow[t]{3}{*}{$\mathrm{NH}_{3}-\mathrm{N}(\mathrm{mg} / \mathrm{dL})$} & 0 & 11.65 & 13.60 & 13.52 & 12.74 & 13.15 & 0.391 & 0.1219 & 0.2471 \\
\hline & 6 & $19.82^{\mathrm{b}}$ & $21.46^{\mathrm{a}}$ & $21.41^{\mathrm{a}}$ & $21.36^{\mathrm{a}}$ & $21.41^{\mathrm{a}}$ & 0.293 & 0.0358 & 0.0073 \\
\hline & 12 & $22.80^{\mathrm{a}}$ & $23.46^{\mathrm{a}}$ & $23.10^{\mathrm{a}}$ & $21.49^{\mathrm{b}}$ & $22.93^{\mathrm{a}}$ & 0.248 & 0.0065 & 0.0053 \\
\hline
\end{tabular}

${ }^{\mathrm{a}-\mathrm{c}}$ Means with different superscripts within a row are significantly different $(p<0.05)$.

${ }^{1}$ Treatments: Control - no inoculant; $10^{6} \mathrm{Cs}-10^{6} \mathrm{CFU} / \mathrm{ml} \mathrm{C.} \mathrm{saccharobutylicum;} 10^{7} \mathrm{Cs}-10^{7} \mathrm{CFU} / \mathrm{ml} \mathrm{C.} \mathrm{saccharobutylicum;} 10^{8} \mathrm{Cs}-10^{8} \mathrm{CFU} / \mathrm{ml} \mathrm{C.} \mathrm{saccharobutylicum;} \mathrm{BA} \mathrm{-}$ $50 \mathrm{mM}$ Butyric acid.

${ }^{2}$ SEM, standard error of mean.

${ }^{3}$ Linear effect (Control $\times$ C. saccharobutylicum supplementation). 


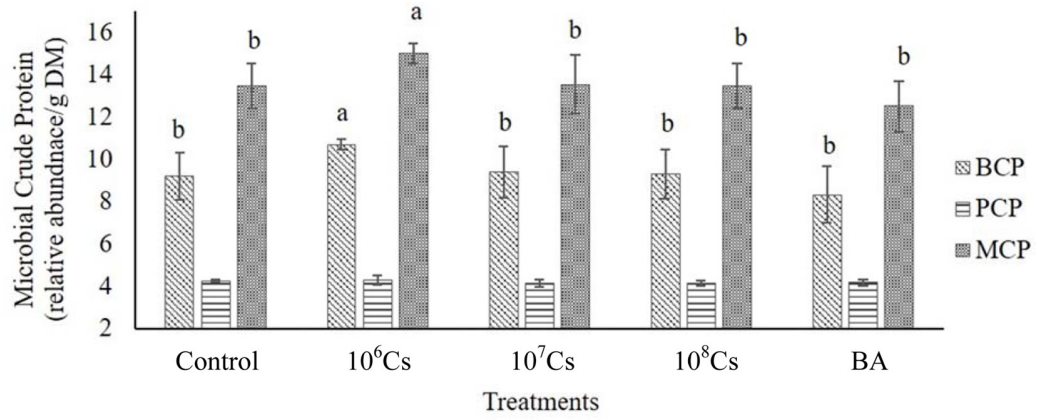

Fig. 3. Effect of C. saccharobutylicum supplementation on microbial crude protein (MCP) at $24 \mathrm{~h}$.

Treatments are as follows: Control - no inoculant; $10^{6} \mathrm{Cs}-10^{6} \mathrm{CFU} / \mathrm{ml} \mathrm{C}$. saccharobutylicum; $10^{7} \mathrm{Cs}-10^{7} \mathrm{CFU} / \mathrm{ml} \mathrm{C}$. saccharobutylicum; $10^{8} \mathrm{Cs}-$ $10^{8} \mathrm{CFU} / \mathrm{ml}$ C. saccharobutylicum; $\mathrm{BA}-50 \mathrm{mM}$ Butyric acid. $\mathrm{MCP}=$ microbial crude protein; $\mathrm{BCP}=$ bacterial crude protein; $\mathrm{PCP}=$ protozoal crude protein. $\mathrm{MCP}=\mathrm{BCP}+\mathrm{PCP}$.

treatments. Meanwhile, increasing the C. saccharobutylicum inoculum supplemented in the samples showed linear effects $(p<0.05)$ on total gas production, $\mathrm{pH}$, acetate, propionate, acetate to propionate ratio and total VFA. At $24 \mathrm{~h}$ incubation, the values decreased as the inclusion rate of C. saccharobutylicum supplemented was increased.

Table 4. Effect of treatments on VFA production (mmol/l) during in vitro rumen fermentation at $0,6,12$, and $24 \mathrm{~h}$.

\begin{tabular}{|c|c|c|c|c|c|c|c|c|c|}
\hline \multirow{2}{*}{ Parameters } & \multirow{2}{*}{ Time (h) } & \multicolumn{5}{|c|}{ Treatments $^{1}$} & \multirow{2}{*}{$\mathrm{SEM}^{2}$} & \multicolumn{2}{|c|}{$p$ value } \\
\hline & & Control & $10^{6} \mathrm{Cs}$ & $10^{7} \mathrm{Cs}$ & $10^{8} \mathrm{Cs}$ & $\mathrm{BA}$ & & All & Linear $^{3}$ \\
\hline \multirow[t]{3}{*}{ Acetate } & 0 & 25.40 & 25.90 & 25.80 & 25.73 & 25.42 & 0.319 & 0.4727 & 0.4596 \\
\hline & 12 & $36.07^{\mathrm{ab}}$ & $37.78^{\mathrm{a}}$ & $34.59^{\mathrm{bc}}$ & $33.49^{c}$ & $37.38^{\mathrm{a}}$ & 0.576 & 0.0071 & 0.0084 \\
\hline & 24 & $37.32^{\mathrm{bc}}$ & $38.08^{\mathrm{ab}}$ & $36.78^{\mathrm{bc}}$ & $36.10^{c}$ & $38.89^{\mathrm{a}}$ & 0.346 & 0.0045 & $<.0001$ \\
\hline \multirow[t]{4}{*}{ Propionate } & 0 & $5.54^{\mathrm{a}}$ & $5.14^{\mathrm{b}}$ & $4.90^{c}$ & $4.79^{c}$ & $4.98^{\mathrm{bc}}$ & 0.041 & $<.0001$ & $<.0001$ \\
\hline & 6 & 10.38 & 10.21 & 10.13 & 10.01 & 9.77 & 0.122 & 0.0828 & 0.0478 \\
\hline & 12 & $11.32^{\mathrm{a}}$ & $11.28^{\mathrm{a}}$ & $11.03^{\mathrm{ab}}$ & $10.63^{\mathrm{b}}$ & $10.54^{\mathrm{b}}$ & 0.145 & 0.0459 & 0.0347 \\
\hline & 24 & $13.16^{\mathrm{a}}$ & $13.04^{\mathrm{a}}$ & $12.93^{\mathrm{a}}$ & $11.26^{\mathrm{b}}$ & $11.43^{\mathrm{b}}$ & 0.271 & 0.0016 & 0.0008 \\
\hline \multirow[t]{3}{*}{ Butyrate } & 0 & $5.39^{\mathrm{b}}$ & $6.71^{\mathrm{a}}$ & $6.60^{\mathrm{a}}$ & $6.46^{\mathrm{a}}$ & $5.72^{\mathrm{b}}$ & 0.151 & 0.0005 & 0.0038 \\
\hline & 6 & $12.00^{\mathrm{d}}$ & $15.37^{\mathrm{a}}$ & $14.49^{\mathrm{ab}}$ & $13.94^{\mathrm{bc}}$ & $13.21^{\mathrm{c}}$ & 0.296 & 0.0009 & 0.0039 \\
\hline & 12 & 15.17 & 16.09 & 15.24 & 15.13 & 13.67 & 0.549 & 0.1915 & 0.7699 \\
\hline \multirow[t]{4}{*}{$\mathrm{A} / \mathrm{P}$ ratio ${ }^{4}$} & 0 & $4.59^{c}$ & $5.03^{\mathrm{b}}$ & $5.27^{\mathrm{ab}}$ & $5.38^{\mathrm{a}}$ & $5.11^{\mathrm{ab}}$ & 0.066 & 0.0008 & 0.0003 \\
\hline & 6 & $3.23^{\mathrm{b}}$ & $3.42^{\mathrm{b}}$ & $3.25^{\mathrm{b}}$ & $3.19^{\mathrm{b}}$ & $3.70^{\mathrm{a}}$ & 0.065 & 0.0029 & 0.4135 \\
\hline & 12 & $3.19^{\mathrm{b}}$ & $3.35^{\mathrm{ab}}$ & $3.14^{\mathrm{b}}$ & $3.16^{\mathrm{b}}$ & $3.55^{\mathrm{a}}$ & 0.076 & 0.0687 & 0.5833 \\
\hline & 24 & $2.84^{c}$ & $2.92^{c}$ & $2.85^{\mathrm{c}}$ & $3.21^{\mathrm{b}}$ & $3.41^{\mathrm{a}}$ & 0.052 & 0.0001 & 0.0037 \\
\hline \multirow[t]{4}{*}{ Total VFA } & 0 & $36.33^{c}$ & $37.76^{\mathrm{a}}$ & $37.29^{\mathrm{ab}}$ & $36.98^{\mathrm{ab}}$ & $36.12^{\mathrm{a}}$ & 0.152 & 0.0001 & 0.0868 \\
\hline & 6 & $55.85^{\mathrm{c}}$ & $60.50^{\mathrm{a}}$ & $57.51^{\mathrm{bc}}$ & $55.93^{\mathrm{c}}$ & $59.04^{\mathrm{ab}}$ & 0.644 & 0.0044 & 0.4361 \\
\hline & 12 & 62.56 & 65.15 & 60.86 & 62.36 & 61.59 & 0.939 & 0.1739 & 0.4037 \\
\hline & 24 & $67.16^{\mathrm{b}}$ & $70.49^{\mathrm{a}}$ & $67.57^{\mathrm{b}}$ & $64.03^{c}$ & $67.06^{\mathrm{b}}$ & 0.492 & 0.0003 & 0.0004 \\
\hline
\end{tabular}

${ }^{\text {a-d }}$ Means with different superscripts within a row are significantly different $(p<0.05)$.

${ }^{1}$ Treatments: Control - no inoculant; $10^{6} \mathrm{Cs}-10^{6} \mathrm{CFU} / \mathrm{ml} \mathrm{C.} \mathrm{saccharobutylicum;} 10^{7} \mathrm{Cs}-10^{7} \mathrm{CFU} / \mathrm{ml} \mathrm{C.} \mathrm{saccharobutylicum;} 10^{8} \mathrm{Cs}-10^{8} \mathrm{CFU} / \mathrm{ml}$ C. saccharobutylicum; BA $50 \mathrm{mM}$ Butyric acid.

${ }^{2}$ SEM, standard error of mean.

${ }^{3}$ Linear effect (Control $\times$ C. saccharobutylicum supplementation).

${ }^{4} \mathrm{~A} / \mathrm{P}=$ acetate to propionate ratio. 


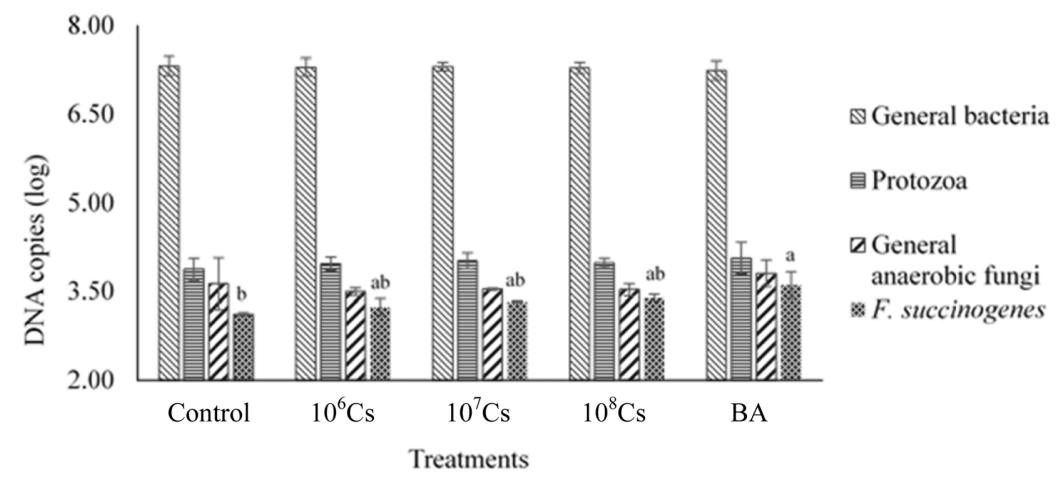

Fig. 4. Quantification of total bacteria, total fungi, protozoa, and Fibrobacter succinogenes by real-time PCR at $24 \mathrm{~h}$.

Treatments are as follows: Control - no inoculant; $10^{6} \mathrm{Cs}-10^{6} \mathrm{CFU} / \mathrm{ml} \mathrm{C}$. saccharobutylicum; $10^{7} \mathrm{Cs}-10^{7} \mathrm{CFU} / \mathrm{ml} \mathrm{C}$. saccharobutylicum; $10^{8} \mathrm{Cs}-$ $10^{8} \mathrm{CFU} / \mathrm{ml}$ C. saccharobutylicum; BA - $50 \mathrm{mM}$ Butyric acid.

\section{Ruminal Microbial Population Abundances}

Supplementation effect of $C$. saccharobutylicum on microbial population in the rumen after $24 \mathrm{~h}$ incubation is shown in Fig. 4. No differences in the abundances of general bacteria, protozoa and general anaerobic fungi were observed among treatments. Meanwhile, there was an increase in the population of Fibrobacter succinogenes when C. saccharobutylicum was supplemented compared with that of the control. Moreover, analysis of the butyrate kinase (buk) gene, which is associated with butyrate producers, showed that supplementation with $10^{6}$ and $10^{7} \mathrm{CFU} / \mathrm{ml}$ of C. saccharobutylicum enhanced the population of butyrate-producing bacteria in the rumen (Fig. 5). However, the butyrate-producing

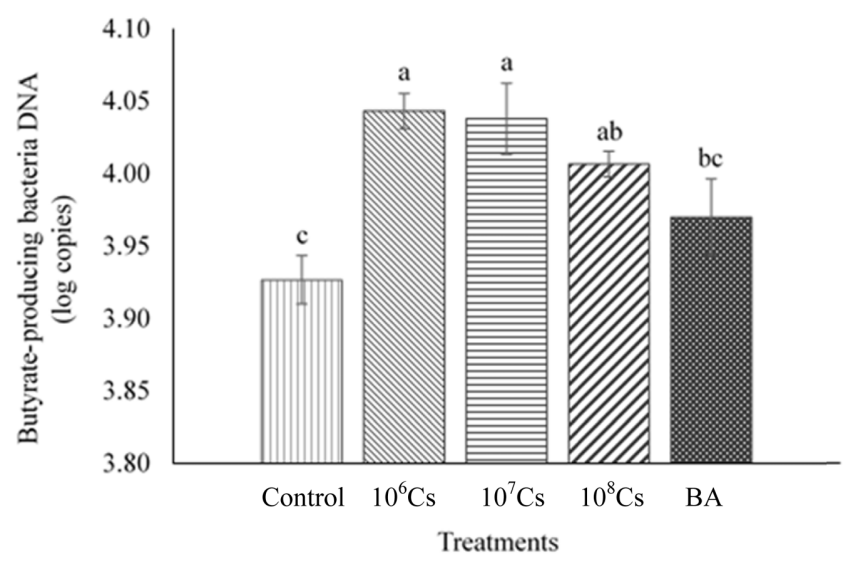

Fig. 5. DNA copies of buk gene of butyrate-producing bacteria during in vitro rumen fermentation at $24 \mathrm{~h}$.

Treatments are as follows: Control - no inoculant; $10^{6} \mathrm{Cs}-10^{6} \mathrm{CFU} / \mathrm{ml}$ C. saccharobutylicum; $10^{7} \mathrm{Cs}-10^{7} \mathrm{CFU} / \mathrm{ml}$ C. saccharobutylicum; $10^{8} \mathrm{Cs}-$ $10^{8} \mathrm{CFU} / \mathrm{ml}$ C. saccharobutylicum; BA - $50 \mathrm{mM}$ Butyric acid. bacteria population tended to decrease, as the inclusion rate of C. saccharobutylicum was increased. Furthermore, this result is in concordance with the butyrate production observed on the in vitro rumen fermentation experiment, wherein the butyrate production decreased as a higher number of $C$. saccharobutylicum was supplemented.

\section{Discussion}

Butyrate is a major product of microbial fermentation in the rumen of ruminants and contributes about $70 \%$ of the daily metabolizable energy requirement for ruminants [34]. Several studies have illustrated the beneficial effect of butyrate in gut health as it plays a significant role in modulating bacterial energy metabolism in the gut ecosystem. Moreover, its effect depends on the diets, microbes and their abundance in the gut ecosystem, and gut transit time $[35,36]$. Butyrate and its derivatives generally exhibit a significant effect on animal production, which includes the enhancement of gut development, control of enteric pathogens, reduction of inflammation, improvement of growth performance, and modulation of gut microbiota [37]. It was also reported that due to their antimicrobial activity, SCFA, including butyrate, have been used as feed additives to control pathogenic bacteria [38, 39]. In ruminants, persistent increase of butyrate level in the GI tract have positive effects on nutrient utilization efficiency [36].

In this study, Clostridium saccharobutylicum RNAL841125 was isolated from the rumen of Holstein-Friesian cow. This bacterium is a Gram-positive, obligately-anaerobic, sporeforming bacterium belonging to Clostridum cluster XIVa and is one of the four distinct species of solvent-producing 
clostridia, along with C. acetobutylicum, C. beijerinckii, and C. saccharoperbutylacetonicum $[33,40,41]$. This bacterium is able to utilize several carbohydrates as the sole source of carbon and energy, converting them into products including acetic and butyric acids, acetone, butanol, ethanol, $\mathrm{CO}_{2}$, and $\mathrm{H}_{2}[33,41]$. In this study, the bacterium utilized a wide range of carbohydrates, including the polymers starch and xylan and saccharides such as glucose, arabinose, xylose, and cellobiose, which is consistent with the findings of Johnson et al. [41]. Weak fermentation was observed in C. saccharobutylicum RNAL841125 on CMC and filter paper; however, no fermentation was observed in pectin as substrate, suggesting that these substrates are not suitable for the growth of this bacterium. Moreover, the only complex polysaccharide not utilized by C. saccharobutylicum is pectin, which consequently, distinguishes this species from C. acetobutylicum, C. saccharoperbutylacetonicum and C. beijerincki [33]. In a study conducted by Meesukanun and Satirapipathkul [42], C. saccharobutylicum BAA 117 was able to utilize the hydrolysate of Cassava rhizome, which consists mainly of cellulose, hemicellulose and lignin, as substrate for fermentation in batch culture. We also found that lower concentrations of enzyme were produced using CMC and filter paper as substrates compared with xylan and starch; these findings may be related to the weak fermentation of the bacterium on these substrates.

The in vitro gas production technique has been used widely to study feed degradation [43]; it can provide important information on the kinetics of feed digestion in the rumen and predicts the substrate utilization efficiency [44]. In this study, our results showed that gas production at 6 and $12 \mathrm{~h}$ has significantly higher value following treatment with $10^{6} \mathrm{CFU} / \mathrm{ml}$ C. saccharobutylicum. This increase in gas production might be attributed to the bacterium's high growth activity; thus, microbial fermentation during the incubation period is high. However, after $24 \mathrm{~h}$ incubation, similar gas production was observed between the control and treatment with $10^{6} \mathrm{CFU} / \mathrm{ml}$ C. saccharobutylicum. Our results were consistent with the results reported by Doto and Liu [45], where addition of a butyrate-producing bacteria, C. butyricum, seemingly had no influence on the rate of gas production at $24 \mathrm{~h}$ incubation.

$\mathrm{pH}$ is the main index reflecting internal homeostasis of the rumen environment; maintaining a relatively stable ruminal $\mathrm{pH}$ is important to ensure efficient rumen fermentation. Our results illustrated a decrease in rumen $\mathrm{pH}$ upon supplementation with $\mathrm{C}$. saccharobutylicum which indicates that the decrease in $\mathrm{pH}$ resulted from the active fermentation of carbohydrates. Moreover, it was reported that mildly acidic $\mathrm{pH}$ values seemed to promote butyrate formation [46]. Furthermore, an in vitro fermentor study with a fecal inoculum [47] demonstrated that two major butyrate-producing bacterial groups, Roseburia/E. rectale species and F. prausnitzii, were found to have thrived at $\mathrm{pH}$ 5.5, whereas their population decreased at $\mathrm{pH}$ 6.5. In accordance with these population changes, it was found that butyrate was the main product of fermentation at $\mathrm{pH} 5.5$, while acetate and propionate were the main products at $\mathrm{pH}$ 6.5. Thus, they suggested that changes in the $\mathrm{pH}$ likely affects the microbial community structure and activity.

Ammonia nitrogen is the vital source of nitrogen for microbial protein synthesis in the rumen [48]. Satter and Slyter (1974) [49] suggested that the lowest concentration of $\mathrm{NH}_{3}-\mathrm{N}$ in rumen liquor should not be less than $5 \mathrm{mg} / \mathrm{dL}$ to maintain higher bacterial growth rate. Moreover, deficit amount of $\mathrm{NH}_{3}-\mathrm{N}$ in the rumen restricts microbial protein synthesis, whereas high concentrations of $\mathrm{NH}_{3}-\mathrm{N}$ also inhibit microbial utilization of this compound [50]. Our results showed that the concentrations of $\mathrm{NH}_{3}-\mathrm{N}$ following treatment with different concentrations of $C$. saccharobutylicum ranged from 23.0 to $23.67 \mathrm{mg} / \mathrm{dL}$, suggesting that growth and protein synthesis of microorganisms were not constrained. Moreover, increased $\mathrm{NH}_{3}-\mathrm{N}$ concentrations indicates a greater catabolism of protein and nonprotein nitrogen [51] and higher nitrogen concentrations are available for microbial utilization and protein synthesis [52, 53]. The study showed that at $6 \mathrm{~h}$ incubation, treatments had higher $\mathrm{NH}_{3}-\mathrm{N}$ concentration compared to control, while at $12 \mathrm{~h}$, treatment supplemented with $10^{8} \mathrm{CFU} / \mathrm{ml}$ C. saccharobutylicum had lower $\mathrm{NH}_{3}-\mathrm{N}$ concentration. However, after $24 \mathrm{~h}$ incubation, no differences in the $\mathrm{NH}_{3}$ $\mathrm{N}$ concentration were observed among treatments. Also, several studies have reported that between a control and probiotics, probiotics have seemingly no effects on the $\mathrm{NH}_{3}-\mathrm{N}$ concentration in the rumen [54, 55]. Furthermore, Kowalski et al. [57] demonstrated that supplementation of $2 \%$ of microencapsulated sodium butyrate had no effect on $\mathrm{NH}_{3}-\mathrm{N}$ concentration in dairy cows. Other studies also revealed that probiotics comprised of Lactobacillus plantarum, Enterococcus faecium and Clostridium butyricum [57] and C. butyricum alone [45] did not influence $\mathrm{NH}_{3}-\mathrm{N}$ concentration.

Microbial crude protein (MCP) is the major source of metabolizable protein for ruminant animals because of its quantity and excellent amino acid profile [58]. In this study, the highest amount of MCP was obtained following treatment with $10^{6} \mathrm{CFU} / \mathrm{ml}$ C. saccharobutylicum. According 
to Block [59], increased MCP production in the rumen improves the efficiency of feed utilization in cattle and results in the supply of a more ideal protein source. In addition, bacterial crude protein (BCP) was also increased following supplementation with $C$. saccharobutylicum. The numerical increase of BCP might be due to the microbial efficiency during fermentation. According to CastilloLopez et al. [60], readily available $\mathrm{N}$ in the form of urea and high starch may have supported more microbial growth leading to more BCP synthesis.

Volatile fatty acids, including butyrate, are considered the most important end products of rumen fermentation providing cows with the majority of energy precursors for metabolic processes [61] and have been established to be significant factors in the postnatal development of the ruminal epithelium [62]. The rumen epithelium is responsible for many important physiological functions including absorption, transport, and SCFA metabolism [37, 63]. In this study, we found that higher concentrations of butyrate was produced following treatment with $10^{6} \mathrm{CFU} / \mathrm{ml}$ C. saccharobutylicum, indicating an increase in the carbon and energy sources for fatty acid synthesis [64]. Several studies had demonstrated that treatment with butyrateproducing bacteria resulted in enhanced butyrate production. In the study by Gorka et al. [65], sodium butyrate supplementation in calves demonstrated that butyrate and total VFA were higher compared with their control treatment, suggesting enhanced rumen fermentation. Moreover, Li et al. [36] illustrated that butyrate infusion affected rapid changes in the rumen VFA concentrations, resulting in an increase in butyrate concentration, while both acetate and propionate concentrations were reduced. Additionally, they showed that butyrate concentration continued to increase and peaked at $168 \mathrm{~h}$ infusion, however, within $24 \mathrm{~h}$ after withdrawal of butyrate infusion, there was a reduction in the ruminal butyrate concentration. In contrast with their report on the decrease of acetate concentration, our study illustrated a minute increase in acetate concentration in treatment with $10^{6} \mathrm{CFU} / \mathrm{ml}$ C. saccharobutylicum until $24 \mathrm{~h}$. This is consistent with the results by Kowalski et al. [56] where the supplementation of $2 \%$ of microencapsulated sodium butyrate increased the acetate concentration. Direct relationship of rumen $\mathrm{pH}$ and VFA is well known, therefore, lower ruminal $\mathrm{pH}$ in treatments supplemented with $C$. saccharobutylicum is related to the increase in ruminal VFA [66].

The addition of microorganisms in the rumen can alter the microbial community in the rumen, and the microbial community changes in response to changes in feed and feed levels in the rumen [67]. The microbial population was not significantly affected by the addition of C. saccharobutylicum; however, cellulolytic bacteria, F. succinogenes increased its population with addition of C. saccharobutylicum, which might suggest that addition of $C$. saccharobutylicum enhances F. succinogenes population. $C$. saccharobutylicum had exhibited hemicellulolytic activity which enables the microorganism to convert a range of agricultural substrates and monomeric sugars of hemicellulose to solvents and acids. The supplementation with C. saccharobutylicum might have stimulated the growth of F. succinogenes leading to the increase in population of this microbe. A study [39] illustrated that butyrate infusion impacted the relative abundance of as many as 6 phyla, including Bacteroidetes, Firmicutes, Fibrobacteres, Synergistetes, Planctomycetes, and Verrucomicrobia. Meanwhile, butyrate-producing bacteria are important to gut homeostasis [68], thus, increasing the population is beneficial in the animal. In this study, the population of butyrate-producing bacteria in the rumen was found to be higher when supplemented with $C$. saccharobutylicum in comparison with that of the control. Our results were consistent with the results of a study by Li et al. [39], who found that an increased butyrate levels in the rumen had stimulatory effects on butyrate-producing bacteria populations. Additionally, they reported that introducing butyrateproducing bacteria into the gut ecosystem is a possible means to treat and prevent colon cancer and enterocolitis, including inflammatory bowel diseases. Meanwhile, the type of diet can also affect the population of butyrateproducing bacteria. In cattle, consumption of high-fiber diets increased the population of major butyrate-producing bacteria, Butyrivibrio, resulting in an elevated butyric acid concentration in the rumen [18]. Furthermore, studies demonstrated that elevated butyrate production in the rumen has a direct stimulating effect on the butyrateproducing bacteria population, or indirect effects, such as metabolic cross-feeding of fermentation products from other bacterial groups [39, 71].

Our study demonstrated that supplementation with $10^{6} \mathrm{CFU} / \mathrm{ml}$ C. saccharobutylicum RNAL841125 has the potential to improve the in vitro rumen fermentation parameters through increased concentration of butyric and total volatile fatty acids, and microbial crude protein. In addition, supplementation with $10^{6} \mathrm{CFU} / \mathrm{ml}$ of $\mathrm{C}$. saccharobutylicum enhanced the population of butyrateproducing bacteria and F. succinogenes. 


\section{Acknowledgments}

This research was supported by the Cooperative Research Program for Agriculture Science and Technology Development, (Project No. PJ013448012018), Rural Development Administration, Republic of Korea.

\section{Conflict of Interest}

The authors have no financial conflicts of interest to declare.

\section{References}

1. Fellner V. 2002. Rumen microbes and nutrient management. Available from https://projects.ncsu.edu/project/swine extension/swinereports/2004-2005/dairycattle/nutrition/fellner1. htm. Accessed Nov. 22, 2018.

2. Chesson A, Forsberg CW. 1997. Polysaccharide degradation by rumen microorganism, pp. 329-381. In The Rumen Microbial Ecosystem. Dordrecht: Springer.

3. Gournier-Chateau N, Larpent JP, Castellanos MI, Larpent JL. 1994. Probiotics in animal and human nutrition, pp. 192. Les probiotiques en Aliment. Anim. Hum. Paris. Technique et Documentation Lavoisier.

4. Jouany JP, Morgavi DP. 2007. Use of "natural" products as alternatives to antibiotic feed additives in ruminant production. Animal 1: 1443-1466.

5. Guedes CM, Gonçalves D, Rodrigues MAM, Dias-da-Silva A. 2008. Effects of a Saccharomyces cerevisiae yeast on ruminal fermentation and fibre degradation of maize silages in cows. Anim. Feed. Sci. Technol. 145: 27-40.

6. Wallace RJ, Colombatto D, Robinson PH. 2008. Enzymes, direct-fed microbials and plant extracts in ruminant nutrition. Anim. Feed. Sci. Technol. 145: 1-4.

7. Wallace RJ. 1994. Ruminal microbiology, biotechnology, and ruminant nutrition: progress and problems. J. Anim. Sci. 72: 2992-3003.

8. Bernardeau M, Vernoux JP. 2013. Overview of differences between microbial feed additives and probiotics for food regarding regulation, growth promotion effects and health properties and consequences for extrapolation of farm animal results to humans. Clin. Microbiol. Infect. 19: 321-330.

9. Aluwong T, Kobo PI, Abdullahi A. 2013.Volatile fatty acids production in ruminants and the role of monocarboxylate transporters: a review. Afr. J. Biotechnol. 9: 6229-6232.

10. Bugaut M. 1987. Occurrence, absorption and metabolism of short chain fatty acids in the digestive tract of mammals. Comp. Biochem. Physiol. B. 86: 439-472.

11. Li X, Højberg O, Canibe N, Jensen BB. 2016. Phylogenetic diversity of cultivable butyrate-producing bacteria from pig gut content and feces. J. Anim. Sci. 94: 377-381.
12. Scheppach W. 1994. Effects of short chain fatty acids on gut morphology and function. Gut 35 Suppl 1: S35-S38.

13. Kato SI, Sato K, Chida H, Roh SG, Ohwada S, Sato S, et al. 2011. Effects of Na-butyrate supplementation in milk formula on plasma concentrations of GH and insulin, and on rumen papilla development in calves. J. Endocrinol. 211: 241-248.

14. Pierce, J., Marjen, M. and Goossens T. 2004. Butyrate: Feeding the gut and beyond for animal health. https:// nutriad.com/2015/01/butyrate-feeding-the-gut-and-beyondfor-animal-health-2/. Accessed 20 Nov. 2018.

15. Canani RB, Di Costanzo M, Leone L. 2012. The epigenetic effects of butyrate: Potential therapeutic implications for clinical practice. Clin. Epigenetics 4(1): 4. doi: 10.1186/18687083-4-4.

16. Vital M, Penton CR, Wang Q, Young VB, Antonopoulos DA, Sogin ML, et al. 2013. A gene-targeted approach to investigate the intestinal butyrate-producing bacterial community. Microbiome 1: 8.

17. Levine UY, Looft T, Allen HK, Stanton TB. 2013. Butyrateproducing bacteria, including mucin degraders, from the swine intestinal tract. Appl. Environ. Microbiol. 79: 3879-3881.

18. Mrázek J, Tepšič K, Avguštin G, Kopečný J. 2006. Dietdependent shifts in ruminal butyrate-producing bacteria. Folia Microbiol. 51: 294-298.

19. Miyazaki K, Martin JC, Marinsek-Logar R, Flint HJ. 1997. Degradation and utilization of xylans by the rumen anaerobe Prevotella bryantii (formerly P. ruminicola subsp. brevis) B14. Anaerobe 3: 373-381.

20. Singh S, Kundu SS. 2011. Comparative rumen microbial population in sheep fed Dicantium annulatum grass supplemented with Leucaena leucocephala and Hardwickia binata tree leaves. Livest. Res. Rural Dev. 23: 117-132.

21. Lane DJ. 1991. 16S/23S rRNA sequencing, pp. 115-175. In Stackebrandt E, Goodfellow M (eds.). Nucleic Acid Techniques in Bacterial Systematics. John Wiley and Sons, Chichester, United Kingdom.

22. Madden T. 2003. The BLAST Sequence Analysis Tool. 2nd edition. NCBI Handbook[internet]. National Center for Biotechnology Information (USA).

23. Yoon SH, Ha SM, Kwon S, Lim J, Kim Y, Seo H, et al. 2017. Introducing EzBioCloud: a taxonomically united database of $16 \mathrm{~S}$ rRNA gene sequences and whole-genome assemblies. Int. J. Syst. Evo.l Microbiol. 67: 1613-1617.

24. Richard C, Beaudouin E, Moneret-Vautrin DA, Kohler C, Nguyen-Grosjean VM, Jacquenet S. 2016. Severe anaphylaxis to propofol: first case of evidence of sensitization to soy oil. Eur. Ann. Allergy Clin. Immunol. 48: 103-106.

25. Tamura K, Stecher G, Peterson D, Filipski A, Kumar S. 2013. MEGA6: molecular evolutionary genetics analysis version 6.0. Mol. Biol. Evol. 30: 2725-2729. 
26. Saitou N, Nei M. 1987. The neighbor-joining method: a new method for reconstructing phylogenetic trees. Mol. Biol. Evol. 4: 406-425.

27. Kimura M. 1980. A simple method for estimating evolutionary rates of base substitutions through comparative studies of nucleotide sequences. J. Mol. Evol. 16: 111-120.

28. Felsenstein J. 1985. Confidence limits on phylogenies: an approach using the bootstrap. Evolution (NY) 39: 783-791.

29. Miller GL. 1959. Use of dinitrosalicylic acid reagent for determination of reducing sugar. Anal. Chem. 31: 426-428.

30. Asanuma N, Iwamoto M, Hino T. 1999. Effect of the addition of fumarate on methane production by ruminal microorganisms in vitro. J. Dairy Sci. 82: 780-787.

31. Chaney AL, Marbach EP. 1962. Modified reagents for determination of urea and ammonia. Clin. Chem. 8: 130-132.

32. Castillo-Lopez E, Klopfenstein TJ, Fernando SC, Kononoff PJ. 2013. In vivo determination of rumen undegradable protein of dried distillers grains with solubles and evaluation of duodenal microbial crude protein flow. J. Anim. Sci. 91: 924934.

33. Keis S, Shaheen R, Jones DT. 2001. Emended descriptions of Clostridium acetobutylicum and Clostridium beijerinckii, and descriptions of Clostridium saccharoperbutylacetonicum sp. nov. and Clostridium saccharobutylicum sp. nov. Int. J. Syst. Evol. Microbiol. 51: 2095-2103.

34. Bergman EN. 1990. Energy contributions of volatile fatty acids from the gastrointestinal tract in various species. Physiol. Rev. 70: 567-590.

35. Li F, Hinderberger J, Seedorf H, Zhang J, Buckel W, Thauer RK. 2008. Coupled ferredoxin and crotonyl coenzyme A (CoA) reduction with NADH catalyzed by the butyryl-CoA dehydrogenase/Etf complex from Clostridium kluyveri. J. Bacteriol. 190: 843-850.

36. Li RW, Wu S, Baldwin VI RL, Li W, Li C. 2012. Perturbation dynamics of the rumen microbiota in response to exogenous butyrate. PLoS One 7: e29392.

37. Bedford A, Gong J. 2018. Implications of butyrate and its derivatives for gut health and animal production. Anim. Nutr. 4: 151-159.

38. Kabara JJ, Swieczkowski DM, Conley AJ, Truant JP. 1972. Fatty acids and derivatives as antimicrobial agents. Antimicrob. Agents Chemother. 2: 23-28.

39. Thormar H, Hilmarsson H, Bergsson G. 2006. Stable concentrated emulsions of the 1-monoglyceride of capric acid (monocaprin) with microbicidal activities against the food-borne bacteria Campylobacter jejuni, Salmonella spp., and Escherichia coli. Appl. Environ. Microbiol. 72: 522-526.

40. Keis S, Bennett CF, Ward VK, Jones DT. 1995. Taxonomy and phylogeny of industrial solvent-producing clostridia. Int. J. Syst. Bacteriol. 45: 693-705.

41. JohnsonN JL, Toth J, Santiwatanakul S, Chen JS. 1997. Cultures of "Clostridium acetobutylicum" from Various Collections Comprise Clostridium acetobutylicum, Clostridium beijerinckii, and Two Other Distinct Types Based on DNADNA Reassociation. Int. J. Syst. Bacteriol. 47: 420-424.

42. Meesukanun K, Satirapipathkul C. 2014. Production of acetone-butanol-ethanol from cassava rhizome hydrolysate by Clostridium saccharobutylicum BAA 117. Chem. Eng. Trans. 37: 421-426.

43. Rymer C, Huntington JA, Williams BA, Givens DI. 2005. In vitro cumulative gas production techniques: history, methodological considerations and challenges. Anim. Feed Sci. Technol. 123: 9-30.

44. Metzler-Zebeli BU, Scherr C, Sallaku E, Drochner W, Zebeli Q. 2012. Evaluation of associative effects of total mixed ration for dairy cattle using in vitro gas production and different rumen inocula. J. Sci. Food Agric. 92: 2479-2485.

45. Doto S, Liu J. 2011. Effects of direct-fed microbials and their combinations with yeast culture on in vitro rumen fermentation characteristics. J. Anim. Feed Sci. 20: 259-271.

46. Cummings JH, Macfarlane GT. 1991. The control and consequences of bacterial fermentation in the human colon. J. Appl. Bacteriol. 70: 443-459.

47. Louis P, Flint HJ. 2009. Diversity, metabolism and microbial ecology of butyrate-producing bacteria from the human large intestine. FEMS Microbiol. Lett. 294: 1-8.

48. Bryant MP. 1974. Nutritional features and ecology of predominant anaerobic bacteria of the intestinal tract. Am. J. Clin. Nutr. 27: 1313-1319.

49. Satter LD, Slyter LL.1974. Effect of ammonia concentration of rumen microbial protein production in vitro. Br. J. Nutr. 32: 199-208.

50. Hristov AN, McAllister TA, Xu Z, Newbold CJ. 2002. Proteolytic activity in ruminal fluid from cattle fed two levels of barley grain: A comparison of three methods of determination. J. Sci. Food Agric. 82: 1886-1893.

51. Soriano AP, Mamuad LL, Kim SH, Choi YJ, Jeong CD, Bae $\mathrm{GS}$, et al. 2014. Effect of Lactobacillus mucosae on in vitro rumen fermentation characteristics of dried brewers grain, methane production and bacterial diversity. Asian-Australasian J. Anim. Sci. 27: 1562-1570.

52. Mamuad L, Kim SH, Jeong CD, Choi YJ, Jeon CO, Lee SS. 2014. Effect of fumarate reducing bacteria on in vitro rumen fermentation, methane mitigation and microbial diversity. $J$. Microbiol. 52: 120-128.

53. Kim SH, Mamuad LL, Kim DW, Kim SK, Lee SS. 2016. Fumarate reductase-producing enterococci reduce methane production in rumen fermentation in vitro. J. Microbiol. Biotechnol. 26: 558-566.

54. Ghorbani GR, Morgavi DP, Beauchemin KA, Leedle JAZ. 2002. Effects of bacterial direct-fed microbials on ruminal fermentation, blood variables, and the microbial populations of feedlot cattle. J. Anim. Sci. 80: 1977-1985.

55. Chiquette J, Allison MJ, Rasmussen M. 2012. Use of Prevotella bryantii $25 \mathrm{~A}$ and a commercial probiotic during 
subacute acidosis challenge in midlactation dairy cows. J. Dairy Sci. 95: 5985-5995.

56. Kowalski ZM, Górka P, Flaga J, Barteczko A, Burakowska K, Oprządek J, et al. 2015. Effect of microencapsulated sodium butyrate in the close-up diet on performance of dairy cows in the early lactation period. J. Dairy Sci. 98: 3284-3291.

57. Qadis AQ, Goya S, Ikuta K, Yatsu M, Kimura A, Nakanishi S, et al. 2014. Effects of a bacteria-based probiotic on ruminal $\mathrm{pH}$, volatile fatty acids and bacterial flora of Holstein calves. J. Vet. Med. Sci. 76: 877-885.

58. Timpka T, Eriksson H, Gursky EA, Strömgren M, Holm E, Ekberg J, et al. 2011. Requirements and design of the PROSPER protocol for implementation of information infrastructures supporting pandemic response: a nominal group study. PLoS One 6: e17941

59. Block E. 2006. Rumen microbial protein production: Are we missing an opportunity to improve dietary and economic efficiencies in protein nutrition of the high producing dairy cow? In: High Plains Dairy Conference. Available from http//.www.highplainsdairy.org/2006/Block-pdf. Accessed Nov. 18, 2018.

60. Castillo-Lopez E. 2012. Intestinal flow of microbial protein and rumen undegradable protein in cattle fed corn distillers grains and solubles, with emphasis during lactation. Vailable from https://digitalcommons.unl.edu/animalscidiss/60/. Accessed Nov. 21, 2018.

61. Storm AC, Kristensen NB, Hanigan MD. 2012. A model of ruminal volatile fatty acid absorption kinetics and rumen epithelial blood flow in lactating Holstein cows. J. Dairy Sci. 95: 2919-2934.

62. Sakata T, Tamate H. 1978.Rumen epithelial cell proliferation accelerated by rapid increase in intraruminal butyrate. J. Dairy Sci. 61: 1109-1113.

63. Graham C, Simmons NL. 2005. Functional organization of the bovine rumen epithelium. Am. J. Physiol. Integr. Comp. Physiol. 288: R173-181.

64. Mamuad LL, Kim SH, Choi YJ, Soriano AP, Cho KK, Lee K, et al. 2017. Increased propionate concentration in Lactobacillus mucosae-fermented wet brewers grains and during in vitro rumen fermentation. J. Appl. Microbiol. 123: 29-40.

65. Gorka P, Kowalski ZM, Pietrzak P, Kotunia A, Kiljanczyk R, Flaga J, et al. 2009. Effect of sodium butyrate supplementation in milk replacer and starter diet on rumen development in calves. J. Physiol. Pharmacol. 3 Suppl: 47-53.

66. Patra RC, Lal SB, Swarup D. 1996. Biochemical profile of rumen liquor, blood and urine in experimental acidosis in sheep. Small Rumin. Res. 19: 177-180.

67. Mao SY, Zhang G, Zhu WY. 2008. Effect of disodium fumarate on ruminal metabolism and rumen bacterial communities as revealed by denaturing gradient gel electrophoresis analysis of $16 \mathrm{~S}$ ribosomal DNA. Anim. Feed Sci. Technol. 140: 293-306.

68. Wang W, Chen L, Zhou R, Wang X, Song L, Huang S, et al. 2014. Increased proportions of Bifidobacterium and the Lactobacillus group and loss of butyrate-producing bacteria in inflammatory bowel disease. J. Clin. Microbiol. 52: 398-406.

69. Flint HJ, Duncan SH, Scott KP, Louis P. 2007. Interactions and competition within the microbial community of the human colon: Links between diet and health. Environ. Microbiol. 9: 1101-1111.

70. Denman SE, McSweeney CS. 2006. Development of a realtime PCR assay for monitoring anaerobic fungal and cellulolytic bacterial populations within the rumen. FEMS Microbiol. Ecol. 58: 572-582.

71. Sylvester JT, Karnati SKR, Yu Z, Morrison M, Firkins JL. 2004. Development of an assay to quantify rumen ciliate protozoal biomass in cows using real-time PCR. J. Nutr. 134: 3378-3384.

72. Yu Y, Lee C, Kim J, Hwang S. 2005. Group-specific primer and probe sets to detect methanogenic communities using quantitative real-time polymerase chain reaction. Biotechnol. Bioeng. 89: 670-679.

73. Sylvester JT, Karnati SKR, Yu Z, Newbold CJ, Firkins JL. 2005. Evaluation of a real-time PCR assay quantifying the ruminal pool size and duodenal flow of protozoal nitrogen. J. Dairy Sci. 88: 2083-2095. 